\title{
A Morphological, Sedimentological and Geophysical Investigation of the Woore Moraine, Shropshire
}

\author{
Aidan A. Parkes ${ }^{1 *}$, Richard I. Waller ${ }^{1}$, Peter G. Knight ${ }^{1}$, Ian G. Stimpson ${ }^{1}$, David I. Schofield ${ }^{2}$ \\ and Keith T. Mason ${ }^{3}$. \\ Research Institute for the Environment, Physical Sciences and Applied Mathematics, Keele \\ University, Keele, Staffordshire, ST5 5BG. \\ British Geological Survey, Kingsley Dunham Centre, Keyworth, Nottingham, NG12 5 GG. \\ Research Institute for Public Policy and Management, Keele University, Keele, Staffordshire, \\ ST5 5BG \\ * Tel: $01782733620 \quad$ E-mail: a.a.parkes@epsam.keele.ac.uk
}

\begin{abstract}
The Bar Hill-Whitchurch-Wrexham Morainic Complex is a large-scale glacial landform thought to represent either the maximum extent or the readvance of the British-Irish Ice Sheet during the Late Devensian. The origin of the moraine remains uncertain as its key characteristics have not been studied in detail due to a lack of exposures from which its large-scale structure can be determined. The development of new technologies has enabled detailed examination of the topography and internal structure of such large-scale landforms. This paper describes a multi-disciplinary approach involving digital geomorphological mapping using enhanced resolution NextMAP ${ }^{T M}$ digital surface models, geophysical imaging (electrical resistivity tomography) and conventional sedimentological analyses. This combination of techniques is useful for elucidating the origin of a large glacial landform in a region of poor exposure. Digital elevation models such as NextMAP $P^{T M}$ offer an efficient and accurate method for landform-mapping, whilst electrical resistivity tomography was able to map the major constituent sediments of the moraine, which had in turn been identified in the single exposure available. Additional geophysical techniques should however be applied to provide further structural data and thereby enable a more detailed interpretation of the moraine's internal structure. Preliminary findings indicate that the moraine is a glaciotectonic landform composed of diamicton and glaciofluvial sediments, an origin consistent with recent suggestions that the Cheshire Plain contained an active ice lobe during the last glacial maximum.
\end{abstract}

\section{Introduction}

The Bar Hill-Whitchurch-Wrexham Morainic Complex (BHWWMC; Boulton and Worsley, 1965) forms a discontinuous double-arcuate loop across the Cheshire plain, from the southern Pennine margins, westwards to the Welsh Borderland. The moraine was first described by Lewis (1894) who suggested that the BHWWMC represents a nationallysignificant landform. Comparison with other terminal moraine complexes within the U.K. such as the Escrick (Cooper and Gibson, 2003); Cromer (Hart, 1990) and Bride (Thomas, 1984) have shown that it is one of the largest. A series of conflicting models have been proposed for the origin of the BHWWMC including: 1) ice stagnation during retreat (Jowett and Charlesworth, 1929; Worsley, 1970); 2) formation during a re-advance (Boulton and Worsley, 1965; Shotton, 1966; Yates and Moseley, 1967); 3) overriding of a pre-existing moraine ridge (Poole and Whiteman, 1961) and, 4) draping of glacial material over a bedrock ridge (McQuillin, 1964). However the mode of origin has remained uncertain, as the moraine's key characteristics have not been examined in detail, due to a lack of significant exposures from which the moraine's internal structure can be constrained. Consequently, conventional techniques used to examine the origin of the well-exposed, coastally-eroded 
landforms such as the Bride (Thomas, 1984) and Cromer moraines (Hart, 1990) are of little help in determining the origin of inland moraines like the BHWWMC.

Recent technological advances in remote sensing and geophysics have enhanced our ability to determine the geomorphology and internal structure of a variety of glacial landforms. Progress in the use of remote sensing to map landforms left by former ice sheets has been well documented by authors including Boulton and Clark (1990); Clark (1997); Smith and Clark (2005); Smith et al., (2006). Probably the most significant advance within the field of remote mapping has been the development of Digital Elevation Models (DEMs; Smith et al., 2006). In particular, the availability of enhanced resolution data sets (e.g. NextMAP'M ) has led to the increasing use of DEMs for the mapping of glacial landforms (Smith et al., 2006; Clark et al., 2009) as they represent a direct quantification of landform morphology (Clark and Meehan, 2001). The integration, manipulation and analysis of DEM data has also been enabled by the development of Geographical Information Systems (GIS) (Napieralski et al., 2007).

Advances in geophysics including the development of new techniques for survey optimisation, new instruments and improved software for data processing and interpretation (Reynolds, 1997), have enabled imaging of the internal structure of landforms that lack exposures. However, in spite of these recent advances, the application of geophysical techniques within formerly glaciated terrestrial environments remains limited. Consequently, the application of geophysical techniques to investigate the internal structure of glacial landforms remains a relatively new field of research (Kulessa et al., 2007).

The aim of this paper is to demonstrate how geomorphological, geological and geophysical techniques can be combined to identify the key characteristics of a major glacial landform lacking significant exposures in order to determine its origin and glaciological significance. This is achieved through: 1) mapping of the surface geomorphology and the delineation of distinctive landform assemblages from enhanced resolution NextMAP ${ }^{\text {TM }}$ digital surface models, 2) geophysical investigation of the internal structure using electrical resistivity tomography and 3) sedimentological and structural analysis of exposed sediments.

\section{Study Area}

The BHWWMC is a major landform associated with ice advance from the north into the Cheshire / Shropshire Plain (Yates and Moseley, 1958). This feature extends across the entire width of the plain as a discontinuous double-arcuate loop, the centre of which impinges upon the mid-Cheshire ridge (figure 1). This landform separates two distinct terrains; the 'fresh' glacial landforms to the north (Paul, 1983) from more subdued morphology to the south (Boulton and Worsley, 1965; Worsley, 1970). Boulton and Worsley (1965) suggested that these terrains are of different age and therefore that the moraine represents the limit of an advance around 20,000 years B.P. Although disputed by Shotton (1967) and Morgan (1973), a recent study by Bowen et al. (2002) argued that the moraine represents the maximum extent of the British-Irish ice-sheet during the Last Glacial Maximum.

This paper focuses upon the easternmost ridge of the BHWWMC at Woore, Shropshire (figure 1), referred to hereafter as the Woore Moraine. The Woore Moraine is located close to the eastern margin of the down-faulted Permo-Triassic rocks of the Cheshire basin and west of the Carboniferous rocks of southern Pennine margins. The moraine is associated with a range of ice-marginal landforms, including an area of hummocky moraine to the 
north-east (Paul, 1983; Goudie, 1990) and an ice-dammed lake to the east (Yates and Moseley, 1958; Rees and Wilson, 1998). The escarpment marking the Pennine margin has been incised by meltwater, producing a series of isolated sandstone ridges. One such ridge is located at Bar Hill, which represents the easternmost point of the Woore Moraine. From this locality the moraine extends west-south-west as a prominent ridge approximately $50 \mathrm{~m}$ above the surrounding plain (Boulton and Worsley, 1965). It has an asymmetric profile, with the southern distal slope generally having a more gentle gradient than the northern proximal slope (Rees and Wilson, 1998).

\section{Methodology}

\subsection{Digital Geomorphological Mapping}

High resolution NextMAP'M Great Britain digital surface models (DSM; $5 \mathrm{~m}$ nominal accuracy and $0.5-1 \mathrm{~m}$ vertical accuracy; Smith et al., 2006) were used to map the geomorphology of the Woore moraine in detail within ArcGIS v9.2. Its perimeter was defined on the basis of significant breaks of slope, identified using topographic profiles generated within ArcGIS. Three profiles orientated transverse to the long-axis of the moraine ridge are displayed in figure 3.

Mapping of a series of smaller-scale landforms on the moraine surface was performed via on-screen digitising (e.g. Clark and Meehan 2001; Hughes et al., 2007; Clark et al., 2009). Following the methodology of Clark et al., (2009), three relief-shaded (hillshade) models were produced. Two models were artificially illuminated from the northwest $\left(315^{\circ}\right.$; figure 2$)$ and the northeast $\left(045^{\circ}\right)$ at an inclination of $45^{\circ}$ to highlight landforms orientated orthogonal to the illumination direction. These models have inherent azimuth-bias (Clark and Meehan 2001) and therefore an additional relief-shade model with a solar illumination inclination of $90^{\circ}$ was generated (e.g. Clark and Meehan 2001). Break of slope was used to delineate the perimeter of individual hummocks, which were then mapped as polygons (Hughes et al., 2007). For the purpose of this study the term hummock is used to describe a positive-relief landform fully bounded by a break of slope. The hummocks were then divided into distinct landform-assemblages based on morphometric data (table 1), calculated using Easy Calculate software (Tchoukanski, 2008). Additional slope angles were derived from a slope model generated from the DSM data (figure 2). An area from each landformassemblage was then geophysically surveyed in order to contrast elements of the moraine's internal structure, ultimately enabling interpretation of the dominant geomorphic processes. Finally, the accuracy of the remote mapping was verified through field observations and comparison with overlain, semi-transparent Ordnance Survey maps.

\subsection{Geophysical Imaging - Electrical Resistivity Tomography}

The necessity for geophysical investigation of the BHWWMC was recognised over 30 years ago by Worsley (1970), who noted the lack of any major exposures from which large-scale internal structures could be examined. However, with the exception of borehole resistivity analyses of seismic shot holes (McQuillin, 1964), no detailed geophysical investigations of the moraine have been undertaken prior to this study. An extensive electrical resistivity tomography (ERT; Reynolds, 1997) survey was designed as part of this investigation. ERT has previously been used to determine apparent resistivity values for glacial materials (e.g. Palacky, 1987; Kilner et al., 2005) and more recently to investigate the internal structure of glacial landforms, identifying interfaces between constituent materials with differing bulk 
resistivity (e.g. Kulessa et al., 2007; Hiemstra et al., 2008). Similarly, ERT has been employed in this study to distinguish between distinctive glacial facies.

ERT data was acquired using an array of up to 64 electrodes connected via multi-core cable to a Campus Tigre resistivity meter. ImagerPro2000 software was used to manage the survey and record the data. The main survey traversed the moraine from north to south in order to provide data for several landform-assemblages and was oriented approximately perpendicular to the moraine's crest-line (figure 3). Farm-field size determined the length of individual surveys, limiting the maximum number of electrodes that could be employed and consequently the depth of imaging potential. In order for the individual surveys to be comparable, a standard Wenner array electrode configuration, with constant $5 \mathrm{~m}$ electrode spacing intervals was used for all surveys. This separation was chosen on the basis of; 1 ) other ERT surveys conducted over similar deposits (e.g. Kulessa et al., 2007), 2) the need to cover two kilometres of terrain in a reasonable time and 3) in order to penetrate to a reasonable depth to test for bedrock (e.g. McQuillin, 1964). Elevation data was collected for each electrode using a Leica 1200 RTK differential GPS base-station and rover-unit system with a relative vertical accuracy of $\sim 2 \mathrm{~mm}$.

Data was processed using the Res2Dinv computer programme (Loke, 2004), using a leastsquares algorithm for the inversion of acquired data. The inversion results were topographically corrected and displayed with a user-defined resistivity contour scale. This scale was determined by identifying a major resistivity change between clay and sand-rich sediments prior to scaling and then assigning a significant colour transition to this boundary.

\subsection{Geological and Structural Investigation}

A single excavation located near to the moraine crest (SJ 722, 423; figure 3) described previously by Rees and Wilson (1998) was revisited. Lithofacies were identified in the field using the terminology of Eyles et al. (1983). Interpretations of the primary sedimentary and tectonic structures within the exposure were made using line drawings (e.g. Williams et al., 2001; Phillips et al., 2002). Particle size analyses on the key lithofacies were conducted on riffled bulk samples of c. $200 \mathrm{~g}$ using wet sieving. Samples were initially soaked in a solution of $30 \mathrm{ml} 0.16$ molar Calgon and $200 \mathrm{ml}$ distilled water for a minimum 24 hour period before being sieved on a stack ranging from $-4 \varnothing(16 \mathrm{~mm}$; pebble) to $+5 \varnothing(31.3 \mu \mathrm{m}$; coarse-medium silt). It was assumed that any deficit in mass was associated with loss of material $<+5 \varnothing$ (i.e. fine silt-clay). GRADISTAT software (Blott and Pye, 2001), was utilised to provide summary statistics of sorting, textural group and median grain size.

\section{Results}

\subsection{Digital Geomorphological Mapping}

Delineation of the Woore Moraine based on break of slope (figure 3 ) shows that it is approximately $9 \mathrm{~km}$ in length, $3-4 \mathrm{~km}$ in width and up to $50-60 \mathrm{~m}$ in height, with an aspect ratio (topographic profile height:width) of 1:60-1:80. The crest of the moraine trends eastnorth-east.

Three profiles illustrate the varied cross-sectional topography of the moraine (figure 3 ). Profile 1 , which is characteristic of the western sector of the moraine, displays proximal (b) 
and distal slopes (a) of similar gradients, with more pronounced undulations on the proximal slope (b). Profile 2, which crosses the highest central part of the moraine (relative relief of $\sim 60 \mathrm{~m}$ ), displays a relatively steep and undulating proximal slope (z), a sharp crest (y) and a comparatively shallow-angled, concave distal slope $(x)$. Profile 3 , characteristic of the eastern sector of the moraine, which features a series of elongate north-south trending hummocks, displays undulating proximal $(\gamma)$ and distal slopes $(\alpha)$ and an ill-defined moraine crest ( $\beta)$.

Mapping of the moraine revealed a complex surface morphology comprising over 140 hummocks superimposed on the moraine ridge that range in size from approximately 70$480 \mathrm{~m}$ in length, $50-230 \mathrm{~m}$ in width and 2-35 $\mathrm{m}$ in height (figure 3). The elongation ratio (Clark et al., 2009) and amplitude of the hummocks were used to discriminate three landform-assemblages (LA1, LA2 and LA3). LA1 was further subdivided in to 3 zones (LA1.1, 1.2 and 1.3; figure 3). The morphometric data for these assemblages is shown in table 1. LA3 is omitted from the table as it lacks hummocks. These landform-assemblages are discussed below:

Landform-Assemblage 1 (LA1)

This zone represents the most extensive landform assemblage and comprises denselypacked hummocks located on both the northern flank and the moraine crest. The hummocks display great variety in both form and size, ranging from sub-conical forms to multi-limbed, sinuous ridges but all form prominent positive relief landforms superimposed on the moraine ridge. The assemblage can be further subdivided into three zones; 1 ) a western zone of relatively large hummocks $(1.1$, table 1$), 2$ ) a central zone of closely-spaced, smaller hummocks, with dispersed larger hummocks $(1.2$, table 1$)$ and 3 ) an eastern zone of large hummocks, similar to the western zone $(1.3$, table 1$)$.

Landform-Assemblage 2 (LA2)

This assemblage is characterised by a series of elongated, sinuous ridges and valleys that trend in an approximately north-south direction. The individual ridges display some of the longest lengths and elongation ratios (1:3.6) values of all the hummocks observed. This assemblage also features smaller, less elongate hummocks located in between the ridges.

Landform-Assemblage 3 (LA3)

This assemblage forms the most distal part of the moraine and is characterised by a distinct lack of hummocks. The assemblage has a relatively gentle topography with associated slope angles as low as $2-3^{\circ}$.

\subsection{Geophysical Imaging - Electrical Resistivity Tomography}

Six individual ERT surveys have been combined to produce a cross-sectional model of resistivity that extends for $1.7 \mathrm{~km}$ north-south across the moraine and covers the first and third landform assemblages ( $L A 1 \& \angle A 3$, figure 4 ). The measured resistitivies have been compared with published resistivity data to identify the likely facies present (table 2).

Landform-Assemblage 1: 
Survey panels 3-6 (figure 4) are representative of $L A 1$, with panel 3 providing information on the distal slope, panel 4 the hill-crest, and panels 5-6 the proximal flank of the moraine. The distal part of panel 3 displays relatively low apparent resistivity values (typically $\leq 100 \Omega \mathrm{m}$ ) that are heterogeneous near the ground surface. This is similar to data collected for $L A 3$ and discussed below. However, the proximal end of panel 3 , which represents the crest of the moraine, reveals a large body with high resistivity values $(\geq 300 \Omega \mathrm{m})$ that outcrops at the surface and dips northwards. Panel 4 shows that the body of resistant material is laterally continuous and underlain by an area of low resistivity at approximately $20 \mathrm{~m}$ depth. Comparison with published resistivity data (Reynolds, 1997) suggests that the high resistance values represent coarse-grained facies, whilst the distal region of low resistance values represents fine-grained materials. Panels 5 and 6 both show lower resistivity values $(\leq 100 \Omega \mathrm{m})$ than seen at the crest of the moraine, though the values are generally slightly higher than those seen in distal regions of the moraine. Heterogeneity in the upper $5 \mathrm{~m}$ of the recorded data is present in panel 5 , but much reduced in panel 6 . However, panel 6 shows a small region of resistivity $\sim 100 \Omega \mathrm{m}$ near the surface, which dips to the north approximately $20 \mathrm{~m}$ beneath the surface.

Landform-Assemblage 3:

Panel 1 of figure 4 is representative of the distal flank (LA3) of the Woore Moraine, whilst panel 2 covers the transition from LA 1-3. Both panels 1 \& 2 show two key features: 1 ) heterogeneity in the upper $5 \mathrm{~m}$ of the profile with resistivity values ranging from $\sim 10 \Omega \mathrm{m}$ to $\sim 300 \Omega \mathrm{m} ; 2$ ) more homogeneous material at depth with resistivity values generally $\leq 100 \Omega \mathrm{m}$. The low resistivity at depth indicates conductive, fine-grained materials, whilst the nearsurface layer is probably composed of a mixture of both fine and coarser-grained materials.

\subsection{Geological and Structural Investigation}

There is only one significant exposure in the moraine. It is located within LA1 between panels 4 and 5 of the ERT survey (figure 4), close to the crest of the moraine near Woore Hall Farm (figure 3). The exposure is approximately $25 \mathrm{~m}$ in length and $5 \mathrm{~m}$ in height and is orientated approximately north-south, perpendicular to the moraine crest. The following sections describe the constituent facies and the structural features present (figure 5).

\subsubsection{Sedimentary facies}

i. Fine Sand (Sh) - Most of the exposure is composed of fine sand, typically a very pale yellow colour when viewed as a fresh surface. The sand shows very fine, millimetrescale laminar bedding, with occasional graded units indicating way up. Bedding where seen within the sand unit is generally sub-vertical and indicates local overturning. The bedding is also truncated in parts by other facies. Particle size analysis of a bulk sample taken from this layer indicates a median grain size $\left(D_{50}\right)$ of $0.15 \mathrm{~mm}$, a moderately-sorted character and contains $3.35 \%$ fines by weight $(<+5 \varnothing)$. Secondary precipitation fronts, visible as a network of slightly cemented red-pink bands, criss-cross the surface of the sand. Some of these precipitation fronts have exploited pre-existing structures within the sand and highlight a series of linear faults (section 4.3.2, figure 6). Occasional bodies of red-brown clay cross-cut the sand units. These bodies are usually clast poor and elongated (figure 7). 
ii. Gravel-Rich Sand (Gfu) - Dispersed within the sand are lenses of gravel-rich sediments, consisting of granule to pebble-sized clasts within a sandy matrix. Rees and Wilson (1998) report that the pebbles consist predominantly of coarsesandstone, quartz and igneous materials. The units show overturned, sub-vertical laminar bedding and grading (figure 8). Particle size analysis of a bulk sample indicates a median grain size $\left(D_{50}\right)$ of $0.53 \mathrm{~mm}$, a very poorly sorted character and $1.14 \%$ fines by weight $(<+5 \emptyset)$.

iii. Matrix-supported diamicton (Dmm) - A stiff diamicton overlies the lower sand unit within the central and northern parts of the exposure. The unit is red-brown in colour, massive and characterised by a fine-grained matrix containing occasional pebble-sized clasts. It also is found as isolated lenses and layers varying in thickness from $\sim 1.5 \mathrm{~m}$ to $30 \mathrm{~cm}$ amongst the sand facies (figure 5). Particle analysis of a bulk sample characterised the material as a slightly gravely sandy mud. The diamicton displays a median grain size $\left(D_{50}\right)$ of $0.03 \mathrm{~mm}$, is poorly sorted and contains $49.6 \%$ by weight of fines $<+5 \varnothing$.

\subsubsection{Structural Features}

The section contains two types of structures:

i. Thrust faults - A series of thrusts have been identified from offset bedding and the juxtaposition of constituent facies. The thrusts (figure 5) have smeared diamicton along the fault plane. The sub-vertical to overturned bedding below the thrust plane suggests that the tilting was a consequence of fault propagation folding forming a footwall syncline below the thrust. The direction of movement along the faults is from the south to the north based on the curvature and truncation of bedding.

ii. High-angle normal (extensional) faults - A series of high-angle normal faults occur principally within the sand unit (see figures 5 and 6 ). The apparent dip of the faults relative to the section is approximately $35-75^{\circ}$ toward the north (northern \& central parts of the section) and south (southern end of the section). These faults have been exploited by secondary iron precipitation fronts, which highlight the fault locations and associated drag of sediments adjacent to the fault plane. These faults offset the reverse faults present within the exposure and consequently are demonstrably younger in age. A fault in the northern end of the exposure is associated with smeared diamicton along the fault, which suggests it may have originated as a reverse fault, before being re-activated as a normal fault.

\section{Interpretation}

\subsection{Woore Moraine Geomorphology}

The Woore moraine is clearly larger than many common moraine types such as seasonal push moraines (Bennett, 2001) and dump moraines (Eyles, 1979; Krüger et al., 2002; 
Benediktsson et al., 2008). Based on its size, geometry and aspect-ratio the Woore Moraine is similar to wide, multi-crested push moraines as described by Bennett (2001) or composite ridges as described by Benn and Evans (1997). These types of moraines are related to largescale glaciotectonism (e.g. Boulton et al., 1999) and have been widely documented within the U.K. (Thomas, 1984; Hart, 1990), continental Europe (van der Wateren, 1981, 1985; Pedersen et al., 1988; Kluiving, 1994) and North America (Oldale and O'Hara, 1984; Sadura et al., 2006).

The topographic profiles also highlight features described at other large push moraines (figure 3). In cross-section, the Woore moraine is characterised by three zones; 1 ) a relatively-smooth distal flank, 2) a hummocky proximal flank and 3) a generally prominent hill-crest. Similar topographic elements have been described at other glaciotectonic moraines, such as the Bride Moraine (Thomas, 1984) and the Paris Moraine (Sadura et al., 2006). Thomas (1984) relates the relatively smooth distal flank of the Bride Moraine to the resedimentation of material from the former crest, whilst Sadura et al., (2006) suggest the presence of an end-moraine fan for the distal flank of the Paris Moraine. The complex proximal flank of the Paris Moraine is thought to reflect an ice-contact slope with icestagnation and differential melting generating the hummocks (Sadura et al., 2006). Finally, the presence of a prominent hill-crest is thought to represent the former position of the icemargin (Sadura et al., 2006). The lack of a prominent hill-crest (profile 1; figure 3) and a change in gross-geomorphology in the western-region of the Woore Moraine may reflect the moraine being over-ridden and reworked (Knight et al., 2007). Consequently, the scale and cross-sectional morphology of the Woore Moraine are consistent with its interpretation as a composite ridge.

The three delineated landform-assemblages provided key localities for both geological and geophysical investigation. The interpretations of each assemblage are discussed below:

\subsection{Landform-Assemblage 1}

\subsubsection{Geomorphology}

The hummocks of $L A 1$ are too large to represent seasonal push (e.g. Bennett, 2001; Ham and Attig, 2001; Sarala et al., in press) or dump features. However, both the processes of; 1) icestagnation (e.g. Andersson, 1997; Evans and Rea, 2005) and 2) thrusting (e.g. Hambrey and Huddart, 1995; Bennett et al., 1998) produce landforms that display similar geometries and forms to those mapped on the Woore Moraine. Rees and Wilson (1998) state that many of the proximal ridges display crestlines orientated parallel with that of the moraine, which is suggestive of a morphological grain (Oldale and O'Hara, 1984). This is consistent with a glaciotectonic origin as individual ridges reflect thrust slices (Kupsch, 1962), whilst hummocks generated through ice-stagnation typically display random crest-line orientations (Andersson, 1997; Ciner et al., 1999). In addition, Rees and Wilson (1998) comment that many ridges display proximal slope angles up to $20^{\circ}$, which are similar to those cited for ridges associated with thrusting (e.g. Bennett et al., 1998), although this is not supported for the majority of ridges on the Woore Moraine by DSM-derived slope angle maps. Consequently, the hummocky proximal flank of the moraine is believed to consist of a combination of ice-stagnation and thrust-generated hummocks.

\subsubsection{Internal Structure}

The exposure at Woore Hall farm is located within LA1 and is composed of heavily-deformed glacial sediments consisting of fine-grained sand, sand and gravel and a clast-poor 
diamicton. The sand facies and sand and gravel facies show laminar bedding, which has been tilted sub-vertically during deformation. The inclusion of granule to pebble-sized gravel within the sands (figures 5 and 8 ) suggests that these units are glaciofluvial in origin. The overlying diamicton is considered subglacial in origin due to: 1 ) its massive structure (Evans et al., 2006), 2) the consolidated nature of the matrix (Evans et al., 2006) and 3) the poor sorting of the matrix (e.g. Boulton, 1978).

It is apparent that the sediments have undergone polyphase deformation (e.g. Phillips et al., 2002). An initial phase of thrusting and the associated folding was generated during icecompression during formation of the moraine. The thrusts are representative of back-thrusts relative to the assumed direction of ice movement. The younger extensional faulting relate either to the melt-out of buried ice or to gravitational spreading following ice-retreat and consequent pressure release (e.g. McCarroll and Rijsdijk, 2003). Unfortunately, due to the small scale of the exposure it is impossible to determine whether this pattern of deformation is indicative of pervasive deformation throughout the whole landformassemblage or whether it represents localised surface phenomena associated with minor oscillations of the former ice margin. However, the presence of tectonised sediments supports the interpretation of the Woore Moraine as a glaciotectonic landform.

The ERT data collected for LA1 shows two distinct zones; 1 ) high-resistivity associated with the hill-crest and 2) a proximal slope characterised by a variable near-surface zone and low resistivity $(<100 \Omega m)$ at depth $(>\sim 6 m)$. The proximity of the exposure at Woore Hall farm to panels 3 and 4 would suggest that an increase in coarse glaciofluvial material is responsible for the increased resistance. These sediments display resistivity values ranging from $100 \Omega \mathrm{m}$ for pure sand to $>600 \Omega \mathrm{m}$ for gravel and sand. A combination of the two with sporadicallydistributed bodies of diamicton, as seen in the Woore Hall exposure, would potentially provide similar results as to those obtained during the survey. This is also consistent with the observation of sandy sub-soil in this part of the profile.

McQuillin (1964) suggested that bedrock may be situated near to the moraine crest. The local Sherwood Sandstone bedrock has published resistivity values ranging from 100-400 $\Omega \mathrm{m}$ (Reynolds, 1997), which is within the range of those identified for the crest. Consequently, the resistivity data could be interpreted as being due to a bedrock ridge close to the surface, either as contiguous basement (e.g. McQuillin, 1964) such as the ridge seen at Bar Hill, or, alternatively as a series of ice-thrust rafts within the glacial material, such as those identified in West Runton, U.K. (Hart and Boulton, 1991). BGS geological maps however show that the Woore Moraine is underlain by Mercia Mudstone bedrock, which has lower resistivity values ( $\leq 60 \Omega \mathrm{m}$; Reynolds, 1997) than those measured at the crest. Therefore uncertainty concerning the likely geology means that the presence of bedrock is currently difficult to assess using ERT alone.

The proximal flank displays two distinct zones. The upper zone of material with mixed resistivity is interpreted as being a combination of both fine-grained diamicton and coarsegrained glaciofluvial materials. The lower resistivity at depth is interpreted as being finegrained diamicton and is supported by Johnson and Menzies (1996) who state that diamicton is most commonly found in the proximal region of end moraines. The presence of some zones of resistivity nearer to $100 \Omega \mathrm{m}$ suggests that there might be bodies of saturated glaciofluvial material present within the proximal flank. The upper surface is interpreted as reworked material. The interface between the two facies is not believed to be the water table, as several trenches we have dug have not contacted the water table at $5 \mathrm{~m}$ depth. 


\subsection{Landform-Assemblage 2:}

\subsubsection{Geomorphology}

The series of elongated, north-south trending ridges and valleys of LA2 are interpreted as erosional features generated by incision of meltwater. This interpretation is based on: 1 ) the complexity of the distal flank revealed by cross-sections, 2) the orientation of the hummocks, which suggests that they are not structurally controlled (e.g. Oldale and O'Hara, 1984 ) and 3) the elongated form of the hummocks. This interpretation is consistent with previous studies that discuss a series of channels of trending north-south across the crest of the moraine (e.g. Yates and Moseley, 1967; Rees and Wilson, 1998). Similar features have been noted by Thomas (1984) on the Bride Moraine. Internal structure data has, to date, not been collected for $L A 2$. In order to test this interpretation ERT will be applied across the landform-assemblage with the hypothesis that the valleys will display higher resistances than the ridges due to infill of coarser glaciofluvial material.

\subsection{Landform-Assemblage 3:}

\subsubsection{Geomorphology}

$L A 3$ is characterised by a shallow-angled and gently undulating slope with an absence of hummocks. This type of profile is similar to the distal flank of the Paris Moraine, which has been identified as end-moraine fan (Sadura et al., 2006). Alternatively the relatively smooth topography of the distal flank of the Bride Moraine has been attributed to subaerial reworking and resedimentation of a former higher crest (Thomas, 1984). Based on the geomorphology and the distal location, $L A 3$ is interpreted as an end-moraine fan (Krzyszkowski and Zieliński, 2002). Krzyszkowski (2002) reports that end-moraine fans are often found superimposed on large-scale glaciotectonic features, which may be associated with steep proximal flanks with slope angles up to $20^{\circ}$. The $2-3^{\circ}$ slope gradient of $L A 3$ is also comparable to late Saalian aged end-moraine fans identified in south-western Poland (Krzyszkowski, 2002).

\subsubsection{Internal Structure}

The ERT for LA3 shows two distinctive layers, which are interpreted as; 1 ) an upper unit of both glaciofluvial and diamicton facies $(\sim 0-5 \mathrm{~m})$ and 2 ) diamicton-dominated sediment at depth $(<\sim 5 \mathrm{~m})$, below the variable near-surface material. The lower layer is consistent with a Type A end-moraine fan detailed by Krzyszkowski and Zieliński (2002), which are dominated by fine-grained materials. However, the presence of some regions of higher resistance at depth (e.g. northern end of panel 1) suggests that coarser, more resistant materials are present at depth within the distal flank. Consequently this suggests the incorporation of glaciofluvial facies, which is more consistent with a type $B$ fan composed of both finegrained mass-flow and coarse-grained waterlain deposits. The varied material in the nearsurface could be representative of reworked sediments following ice-retreat as suggested by Thomas (1984), or glaciofluvial material relating to the presence of the end-moraine fan.

\subsection{Interpretation Summary}

In summary, the geomorphological evidence shows that the Woore Moraine is of similar size and scale to composite ridges and displays topographic elements described for other 
glaciotectonic landforms, including a hummocky ice-contact slope, a relatively smooth distal end-moraine fan and a series of elongated ridges and valleys, interpreted as melt-water channels. Dominant sediment facies identified within the proximal flank consist of glaciofluvial sediments and a subglacial diamicton. The ERT survey suggests that both the distal and proximal flanks of the moraine are largely composed of clay-rich material. The crest of the moraine is composed of more resistant material, which either represents the predominance of glaciofluvial facies or alternatively, rafts composed of the local Sherwood Sandstone bedrock. The deformation of the sediments within the exposure at Woore Hall farm suggests that the proximal hummocks are associated with a combination of thrusting and ice-stagnation.

\section{Discussion}

Whilst numerous studies describe the structure of glacial landforms within well-exposed, formerly glaciated environments, inland relict glacial environments with poor exposure have been less well studied. This study has demonstrated that a multidisciplinary approach, utilising a range of new technologies including improved mapping techniques, data sources and geophysical equipment, can be used to investigate the topography, internal structure and origin of large landforms in these environments.

\subsection{Digital Geomorphological Mapping}

Landform mapping utilising DEMs has become very popular (Chiverrell et al., 2008) and the advantages and disadvantages compared with other data types have been discussed by authors including Clark and Meehan (2001) and Smith et al., (2006). From the perspective of this study, enhanced resolution DSMs have provided an opportunity to constrain the surface geomorphology of the Woore Moraine for the first time. Relief-shaded models have revealed a topographic complexity that has not been previously appreciated. Mapping using GIS and NextMAP ${ }^{\mathrm{TM}}$ data is also associated with various benefits. First, digital mapping can be undertaken more rapidly than conventional field mapping. Second, the high resolution of the data allows the accurate mapping of small-scale landforms. Third, the superior spatial coverage of the digital data enables meso-scale landform patterns to be resolved, whilst avoiding micro-scale complexities. Fourth, digital mapping enables large quantities of morphometric data to be collected, which can be utilised for comparison with other landforms or as in this project, to delineate a series of landform-assemblages. Finally the ability to generate a range of derivates from the raw DEM data (e.g. slope angle maps, crosssectional profiles) is a powerful tool in landform delineation and interpretation.

However, the validity of glaciological interpretations based solely on geomorphological analyses has been questioned by Waller and Tuckwell (2005) and Lindén et al., (2007) amongst others, with landforms of varied origins frequently displaying similar forms. Lindén et al. (2007) therefore argue that sedimentological and structural investigations are also required in order to generate more reliable interpretations. In areas where natural or quarry-related exposures are lacking, the application of geophysical techniques provides an alternative means of investigating the internal structure of large landforms (e.g. Bakker, 2004; Kulessa et al., 2007).

\subsection{Geophysical Imaging - Electrical Resistivity Tomography}

Whilst ground penetrating radar (Bakker, 2004; Bennett et al., 2004) and to a lesser extent seismic techniques (Harris et al., 1997; Kulessa et al., 2007), have been used to image the structure of glacial landforms in both modern-day and Pleistocene settings, ERT has only 
recently been utilised (Kulessa et al., 2007, Hiemstra et al., 2008). ERT has been employed in this study to map lateral and vertical material changes within the moraine and to investigate whether or not bedrock is present. Using published data we have been able to relate the acquired bulk resistivity values to likely particle-size characteristics and thereby map changes in the dominant sediment facies. The application of ERT within this setting has identified a series of benefits and potential weaknesses.

The primary benefit of geophysical surveying is its ability to constrain the internal structure of a landform in three dimensions, even in the absence of other subsurface data (e.g. sections, boreholes etc.; Kulessa et al., 2007). This is especially apparent for ERT, which enables lateral and vertical changes in resistivity related to facies variations to be mapped over large areas. Second, the resolution of ERT data can easily be altered to suit the objectives of the study. By increasing or decreasing the electrode spacing, ERT can be used to undertake both highly-detailed, near-surface surveying or low-resolution surveying to a greater depth. However, it is worth noting that the coarser the resolution of the ERT data, the poorer its ability to resolve sedimentary features. For example, in the case of this study, minor features such as thin sedimentary layers or lenses could not be resolved (Kilner et al., 2005). Third, ERT can be utilised within a wide range of field conditions, including both highly resistant and highly conductive sediments (Smith and Sjogren, 2006). In comparison GPR suffers when there is a high content of fine material (e.g. clay) in the subsurface due to attenuation of the electromagnetic energy (Reynolds, 1997). Seismic reflection data is much more difficult to acquire and process (Smith and Sjogren, 2006), whilst seismic refraction has the potential to be useful it suffers from poor resolution. Fourth, ERT provides information on the nature of the constituent sediments, in contrast to either seismic techniques or GPR, which highlight interfaces and therefore provide more structural detail (Kristensen et al., 2009). Fifth, data acquisition is fairly rapid as it is largely automated. This automation makes ERT surveying ideal for application in conjunction with other more laborious geophysical techniques such as GPR that require user participation for the collection of data.

One weakness of ERT data is that published resistivity values span large ranges, which in turn limits the extent to which distinctive sediment types can be distinguished. Consequently, where possible in-situ resistivity readings should be collected using an earth ground tester / resistivity meter, to allow the acquisition of more accurate, site specific resistivity values which can improve the extent to which key facies can be discriminated within larger surveys. Second, ERT sections provide limited structural data (Kristensen et al., 2009). Therefore, the technique should ideally be applied in combination with other geophysical techniques, such as GPR and seismic techniques, enabling both structural features and sedimentary facies to be identified.

\subsection{Origin \& Glaciological Significance}

The preliminary geomorphological, geophysical and sedimentological evidence reported here suggests that the Woore moraine's characteristics are consistent with a glaciotectonic origin. Whilst an alternative origin through the ice-marginal dumping of sediment (Jowett and Charlesworth, 1929) related to ice stagnation (e.g. Boulton, 1968) could produce a landform of similar size and surface morphology (e.g. Krüger, 1994), it is inconsistent with the moraine's internal structure. In addition, where such features have been observed at modern-day glaciers (e.g. Krüger, 1994) a large part of their volume relates to the existence of buried ice. Subsequent ablation would inevitably result in a final landform of smaller size and more varied topography. Current evidence supports a dynamic former ice margin (e.g. Thomas and Chiverrell, 2007; Bradwell et al., 2008) and it is therefore improbable that a moraine the size of the BHWWMC would be deposited at a stagnant ice front. 
Recent numerical modelling of the British ice-sheet during the Last Glacial Maximum has suggested fairly rapid basal velocities within the Cheshire Plain (Boulton and Hagdorn, 2006). As such, an advance of this ice lobe has the potential to form a composite ridge, which in both Spitsbergen and Iceland have been related to fast ice flow (Croot, 1987; Drozdowski, 1987; Benn and Evans, 1997). The presence of a hummocky proximal slope and an extensive region of hummocky topography north of the moraine complex (Paul, 1983) could also be viewed as part of a surging glacier landsystem (Evans and Rea, 2005). The deformation of sediments seen at Woore Hall farm cannot be relied on as evidence of pervasive deformation however, due to the small scale of the exposure and the tectonisation of these materials may have been due to seasonal oscillations of an ice-margin. Future excavations and the application of GPR and seismic geophysical techniques will provide additional data to determine the extent of deformation observed within the section.

\subsection{Future Work}

Further work on the Woore Moraine will involve the acquisition of additional ERT data, including the completion of a second survey line and a series of gridded ERT surveys along the main survey line. Additional geophysical techniques, including both GPR and seismic refraction will also be utilised. These additional surveys will provide essential data for the development of 3-D sediment-assemblage model of the Woore Moraine, whilst providing further insight into the applicability of different types of geophysical techniques in previously glaciated terrains. A series of shallow excavations will also be undertaken to enable: 1) the identification and description of the near-surface sedimentary facies, 2) the ground-truthing of the geophysical data and, 3) the collection of in-situ resistivity data. Samples collected from the trenches will also be used for OSL dating in order to constrain the timing of the moraine's genesis.

\section{Conclusions}

A multidisciplinary approach utilising a combination of geomorphological mapping, geological and geophysical techniques is a promising approach in the investigation of the origin of glacial landforms where there is a lack of exposure. Geomorphological mapping can be used to delineate key landform-assemblages, the internal structure of which can then be investigated utilising various geophysical techniques, the results of which can be validated through the examination of available exposures or artificial excavations.

ERT can be used to map bulk resistivity changes across large landforms and therefore can be used to map the interfaces between sedimentary facies, particularly clay / diamictondominated and stratified, sand-dominated facies. Although ERT can be used as a standalone surveying technique, because of its limited ability to resolve structural feature we suggest that it is best combined with other geophysical techniques in order to provide more detailed reconstructions of subsurface properties. Both GPR (e.g. Bakker, 2004) and seismic methods (e.g. Harris et al., 1997; Kulessa et al., 2007) provide suitable companion techniques, as they examine different geophysical properties.

The key characteristics of the Woore Moraine are similar to glaciotectonic moraines described elsewhere (e.g. wide, multi-crested push moraines; Bennett, 2001). It displays a complex surface morphology comprising three landform-assemblages: 1) a hummocky proximal slope interpreted as an ice-contact face, 2 ) a series of ridges and valleys 
perpendicular to the crest interpreted as melt-water channels and, 3) a gently sloping and gently undulating distal flank interpreted as an end-moraine fan, a depositional environment that has not been previously suggested for the Woore Moraine. The ERT survey revealed three distinct zones of material within the moraine. First, a distal slope composed of low resistivity material, interpreted as being representative of an end moraine fan composed of clay-dominated material. Second, a region of high resistivity around the crest of the moraine either associated with an increase in glaciofluvial material dominance as exposed at Woore Hall Farm, or possibly the presence of bedrock (e.g. McQuillin, 1964) in the form of tectonised rafts. Third, a proximal slope associated with low resistivity interpreted as being dominated by fine-grained diamicton. Geological and structural analysis of a single exposure revealed the presence of both glaciofluvial sand and gravel facies and a subglacial diamicton that have undergone polyphase glaciotectonic deformation. Future work will involve the application of both GPR and seismic refraction geophysical techniques will be applied in the future in order to determine whether deformation is pervasive and enable a more robust model of the moraine's origin to be constructed. Additionally, it will provide further insight into the applicability of geophysical techniques within formerly glaciated environments. This preliminary interpretation of the Woore Moraine as a composite ridge is consistent with recent numerical models (e.g. Boulton and Hagdorn, 2006) that suggest rapid basal velocities for the British-Irish ice sheet within the Cheshire Plain.

\section{Acknowledgements}

The authors gratefully acknowledge the financial support of the EPSAM Research Institute, Keele University who have funded A.A. Parkes' studentship, as well as the logistical support and training provided by the Applied Environmental Geophysics Group. We also thank the British Geological Survey who provided access to the NextMAP'M Great Britain data.

Additional funding to support the fieldwork was provided by the Royal Geographical Society (with the Institute of British Geographers) via a Postgraduate Research Award. David Schofield publishes with the permission of the Executive Director, British Geological Survey. We would also like to thank the following landowners for providing access to their land: Jane and Steve Ellsmoor of Dorrington Hall Farm, Paul Platt of Woore Hall Farm, Tony Swires of Cottage Fields Farm, Yvonne and Mark Braithwaite of Gorsey Bank Cottage and Jon Sutton of Oak Farm. 
Tables

\begin{tabular}{|c|c|c|c|c|c|}
\hline & & $\begin{array}{l}\text { LA1.1 } \\
\mathrm{n}=34\end{array}$ & $\begin{array}{l}\text { LA1.2 } \\
\mathrm{n}=55\end{array}$ & $\begin{array}{l}\text { LA1.3 } \\
\mathrm{n}=39\end{array}$ & $\begin{array}{c}\text { LA2 } \\
\mathrm{n}=15\end{array}$ \\
\hline \multirow[t]{3}{*}{ Length ( $\mathrm{m}$ ) } & Mean & 314 & 190 & 369 & 477 \\
\hline & Min & 132 & 71 & 75 & 103 \\
\hline & Max & 934 & 649 & 921 & 1109 \\
\hline \multirow[t]{3}{*}{ Width (m) } & Mean & 176 & 115 & 195 & 226 \\
\hline & Min & 76 & 52 & 49 & 94 \\
\hline & Max & 520 & 391 & 815 & 527 \\
\hline \multirow[t]{3}{*}{ Perimeter $\left(\mathrm{m}^{2}\right)$} & Mean & 832 & 520 & 937 & 1220 \\
\hline & Min & 345 & 202 & 217 & 322 \\
\hline & Max & 2640 & 1588 & 2777 & 2728 \\
\hline \multirow[t]{3}{*}{ Area (m) } & Mean & 48802 & 19396 & 66046 & 90455 \\
\hline & Min & 8439 & 2736 & 3387 & 7771 \\
\hline & Max & 354791 & 121231 & 506334 & 327109 \\
\hline \multirow[t]{3}{*}{ Height (m) } & Mean & 12 & 8 & 15 & 12 \\
\hline & Min & 5 & 2 & 3 & 6 \\
\hline & Max & 33 & 31 & 29 & 27 \\
\hline \multirow{3}{*}{$\begin{array}{l}\text { Elongation Ratio } \\
\text { (Length / Width) }\end{array}$} & Mean & 1.9 & 1.7 & 2 & 2 \\
\hline & Min & 1.1 & 0.9 & 1.1 & 1.1 \\
\hline & Max & 2.9 & 3.4 & 4.2 & 3.6 \\
\hline \multirow{3}{*}{$\begin{array}{l}\text { Amplitude } \\
\text { (Height / Width) }\end{array}$} & Mean & 0.07 & 0.07 & 0.08 & 0.05 \\
\hline & Min & 0.03 & 0.01 & 0.02 & 0.03 \\
\hline & Max & 0.14 & 0.17 & 0.2 & 0.1 \\
\hline \multicolumn{2}{|l|}{$\begin{array}{l}\text { Standard Deviation } \\
\text { Length }\end{array}$} & 153.8 & 110.9 & 192.7 & 311.8 \\
\hline
\end{tabular}

Table 1 - Morphometric measurements of 143 hummocks identified from mapping of the Woore moraine. LA3 has been omitted from the table as it is characterised by a lack of hummocks.

\begin{tabular}{lll}
\hline Material & Nominal Resistivity $(\Omega \mathrm{m})$ & Source / Notes \\
\hline Moraine & $10-5 \times 10^{3}$ \\
'Boulder Clay' & $15-35$ \\
Clay (very dry) & $50-150$ \\
Quaternary / Recent Sand & $50-100$ \\
Gravel (dry) & 1400 \\
Gravel (saturated) & 100 \\
Clays & $1-100$ \\
Clays & $\sim 5-100$ \\
Tills & $\sim 70-\sim 3,000$ \\
Gravel and Sand & $\sim 600-10,000$ \\
& & \\
Bedrock & $100-400$ & \\
Sherwood Sandstone & $20-60$ & Reynolds (1997) \\
Mercia Mudstone & Palacky (1987)
\end{tabular}

Table 2: Table showing common resistivity values of glacial sediments and bedrock within the study area. 
Figures

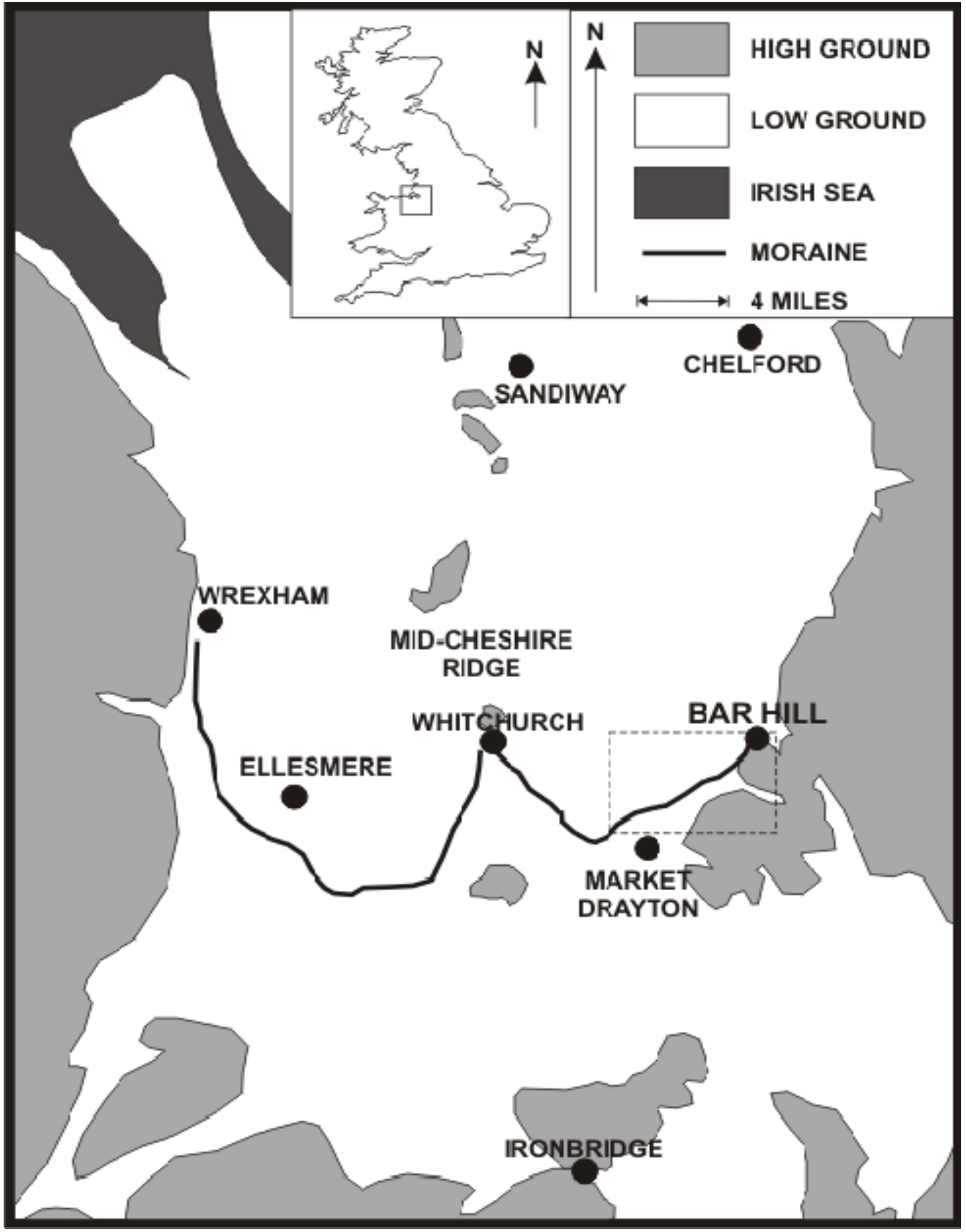

Figure 1 - Map of the Cheshire Basin, showing the location of the Bar Hill-WhitchurchWrexham Moraine. The dashed box highlights the Woore Moraine. Inset map shows the location of the morainic complex within the UK.

(Image after: Boulton and Worsley, 1965). 

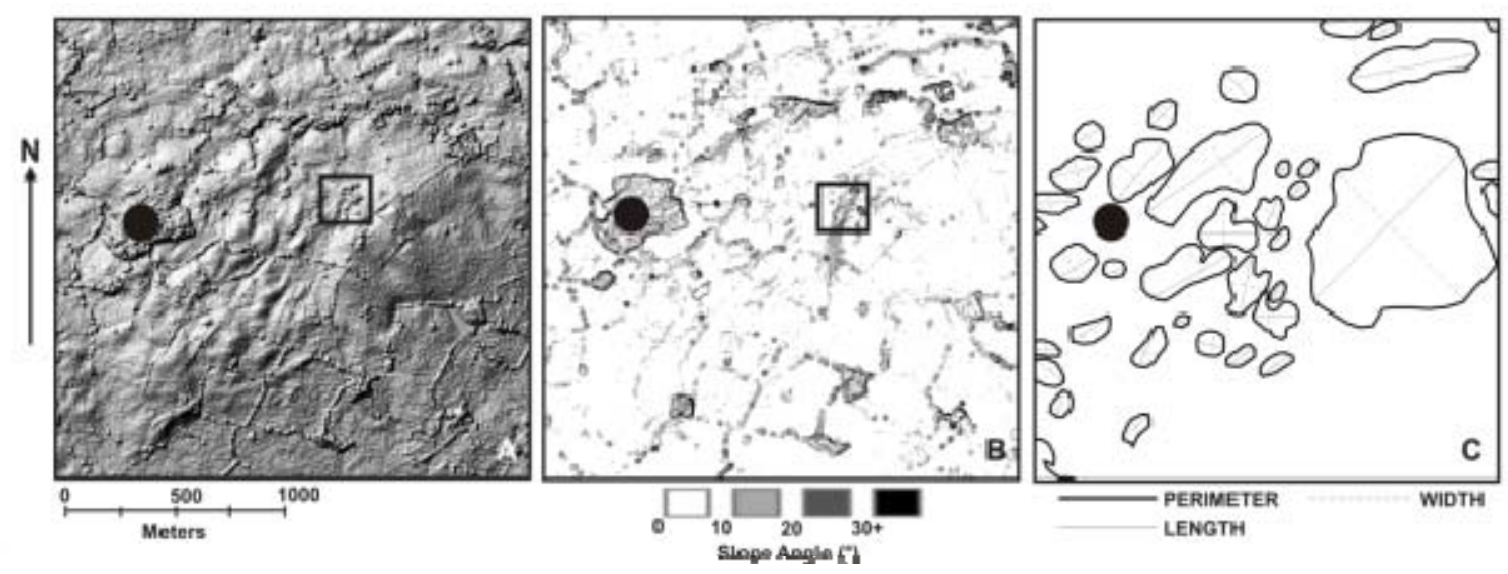

Figure 2 - Illustration of the DEM derivates used to map the glacial geomorphology of the Woore Moraine. A combination of relief-shaded models (in this case illuminated from $315^{\circ}$ )

(A), and slope models (B) were used to delineate surface hummocks (C). The black dot highlights an area of woodland whilst the box in (A) and (B) highlights Woore Hall Farm (cultural noise). 


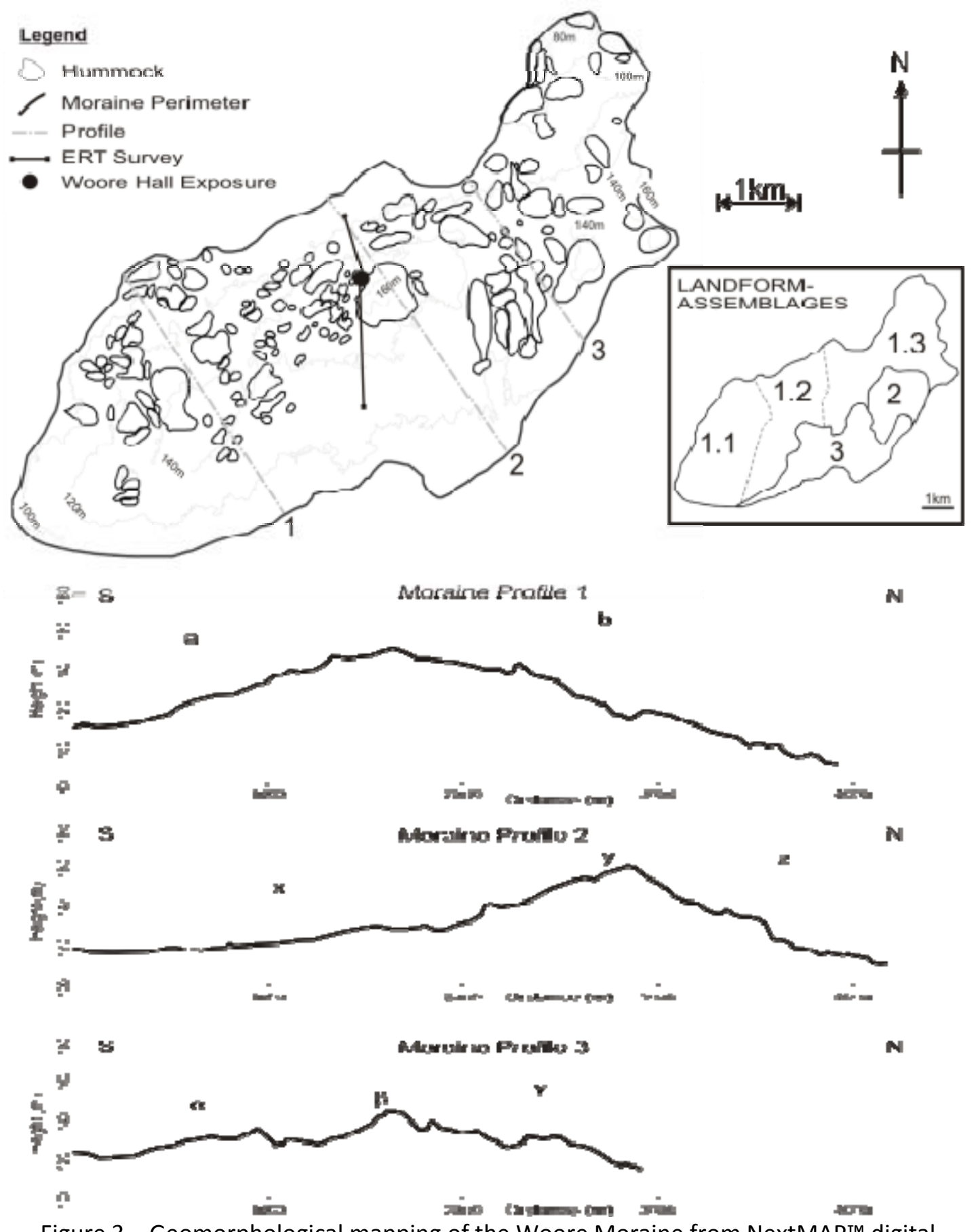

Figure 3-Geomorphological mapping of the Woore Moraine from NextMAP ${ }^{\text {TM }}$ digital surface models and topographic profiles of the cross-sectional geomorphology. Lettered areas on the profiles correspond to text in section 4.1. 

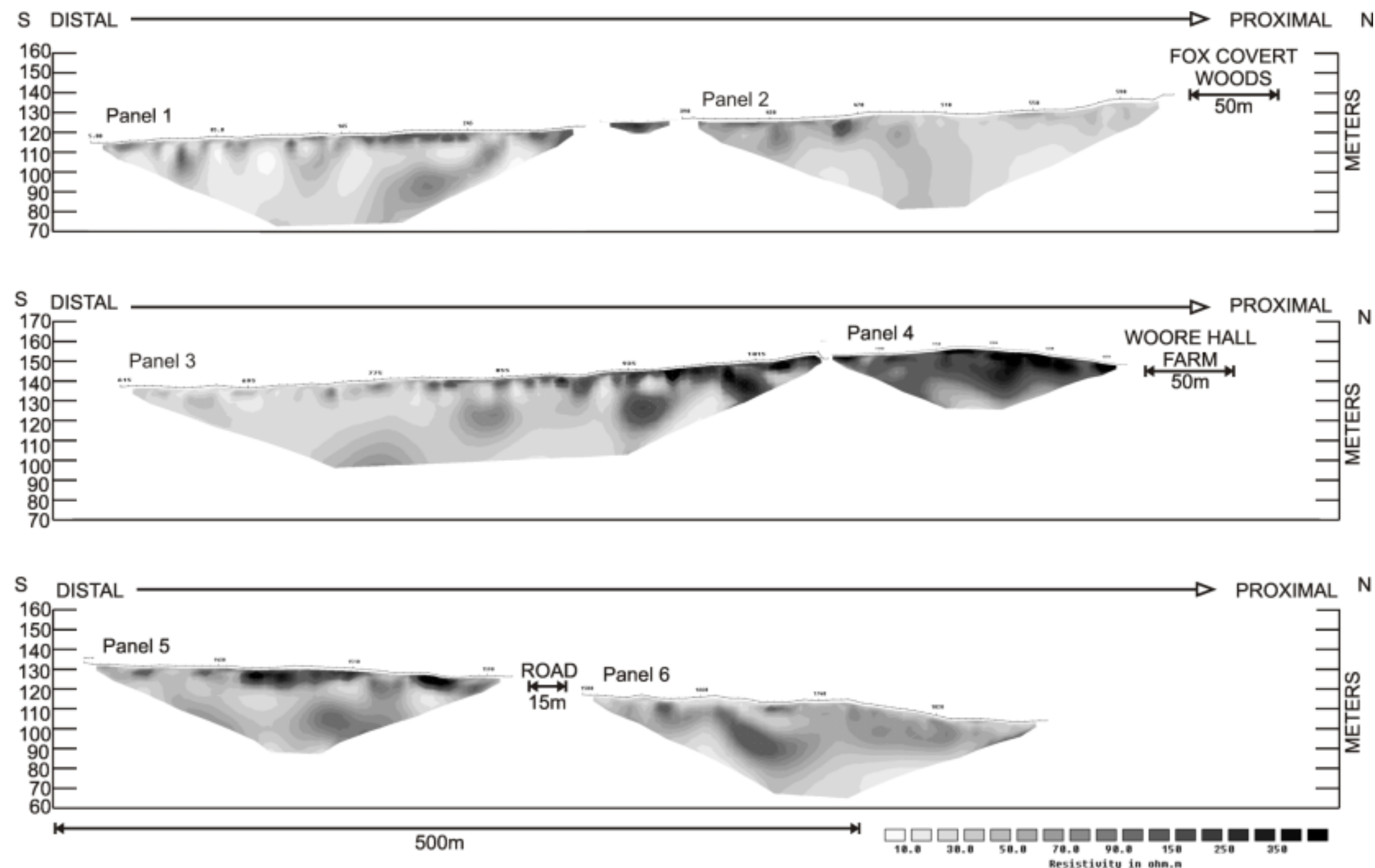

Figure 4 - ERT cross-section across the Woore Moraine, generated from 6 individual survey panels 

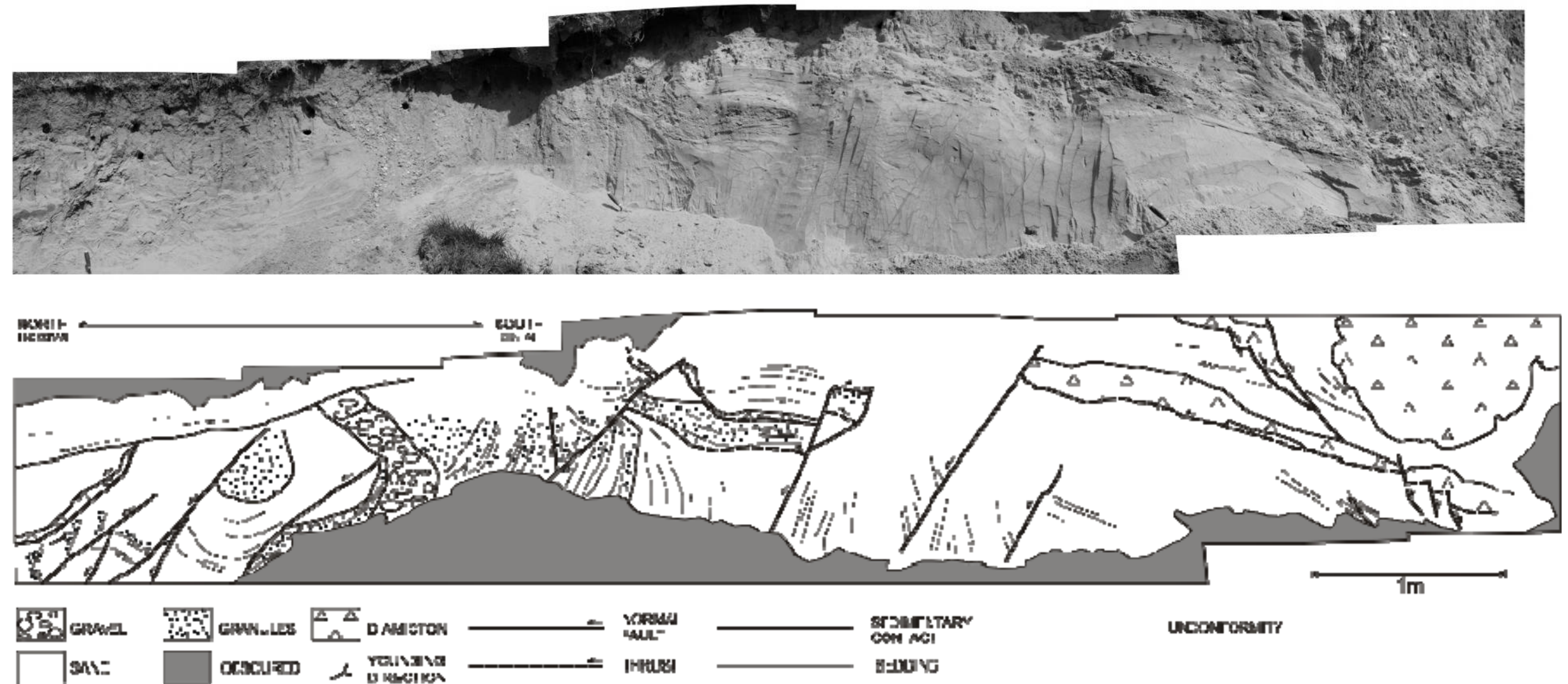

Figure 5 - Photo montage and line drawing interpretation of the constituent sediments and structural features present in the exposed section at Woore Hall Farm. 


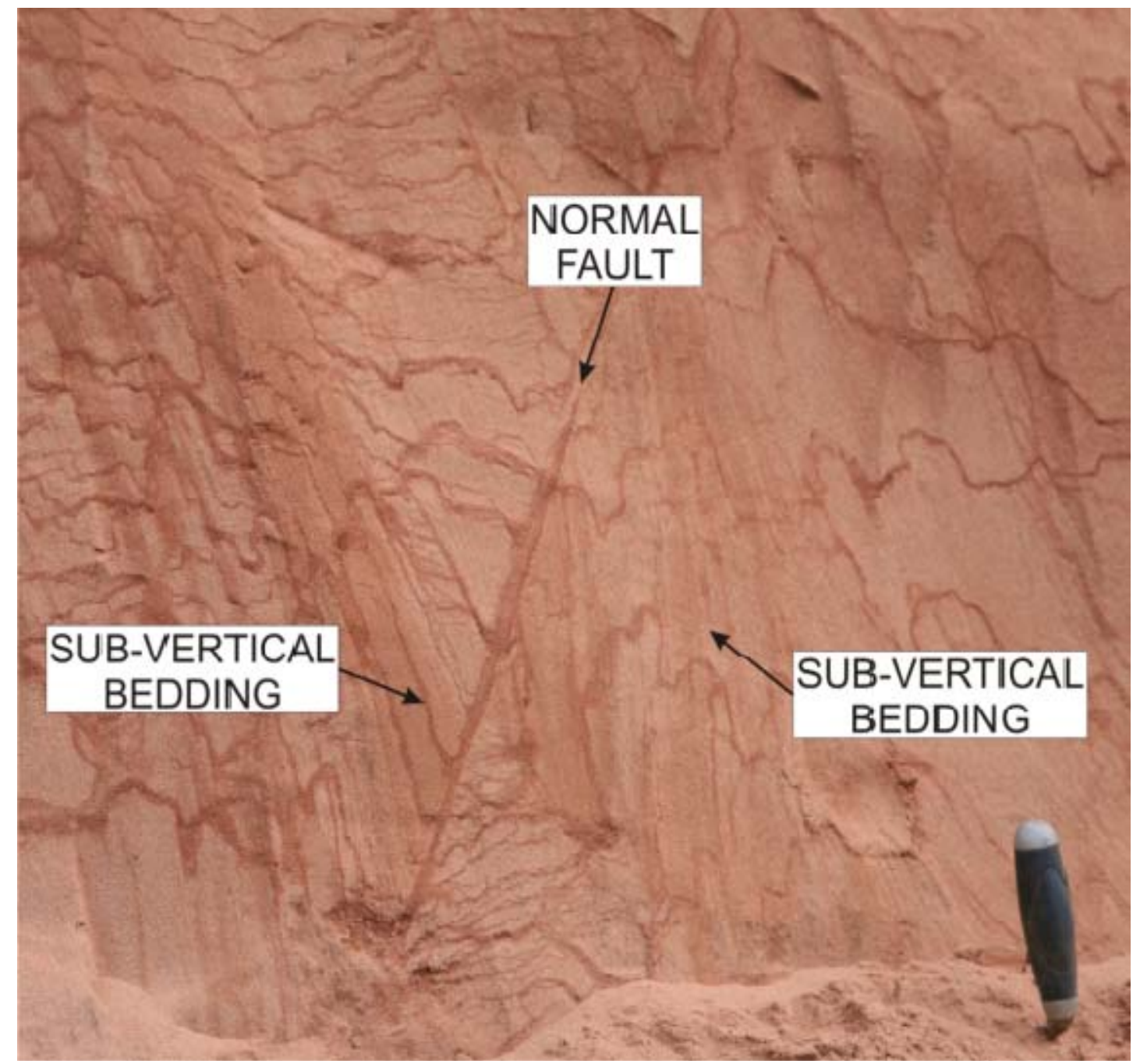

Figure 6 - Secondary precipitation front utilising pre-existing structures within the exposure at Woore Hall farm. Trowel for scale. 


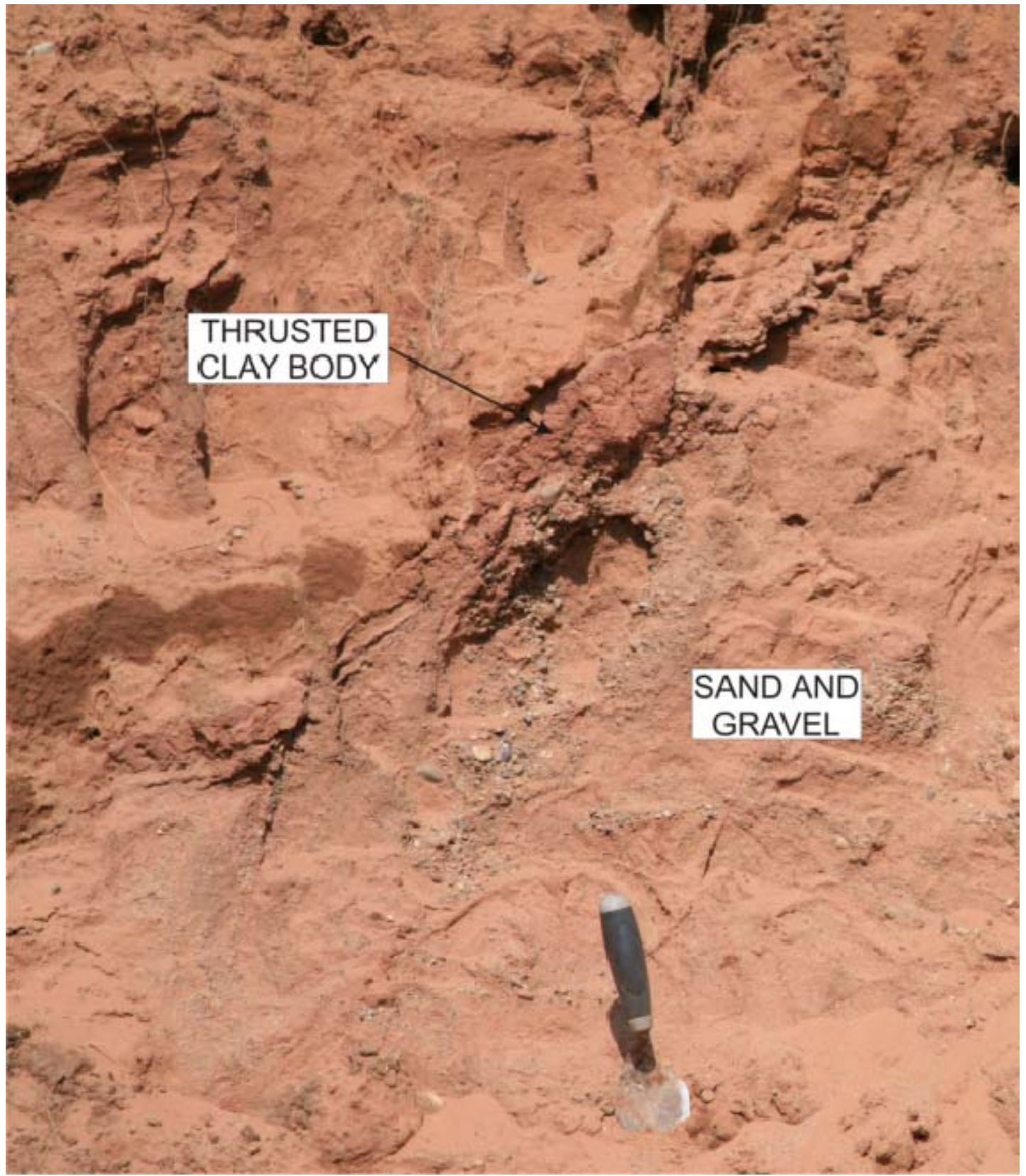

Figure 7 - Elongated clay bodies amongst the fine sand exposed at Woore Hall Farm. Trowel for scale. 


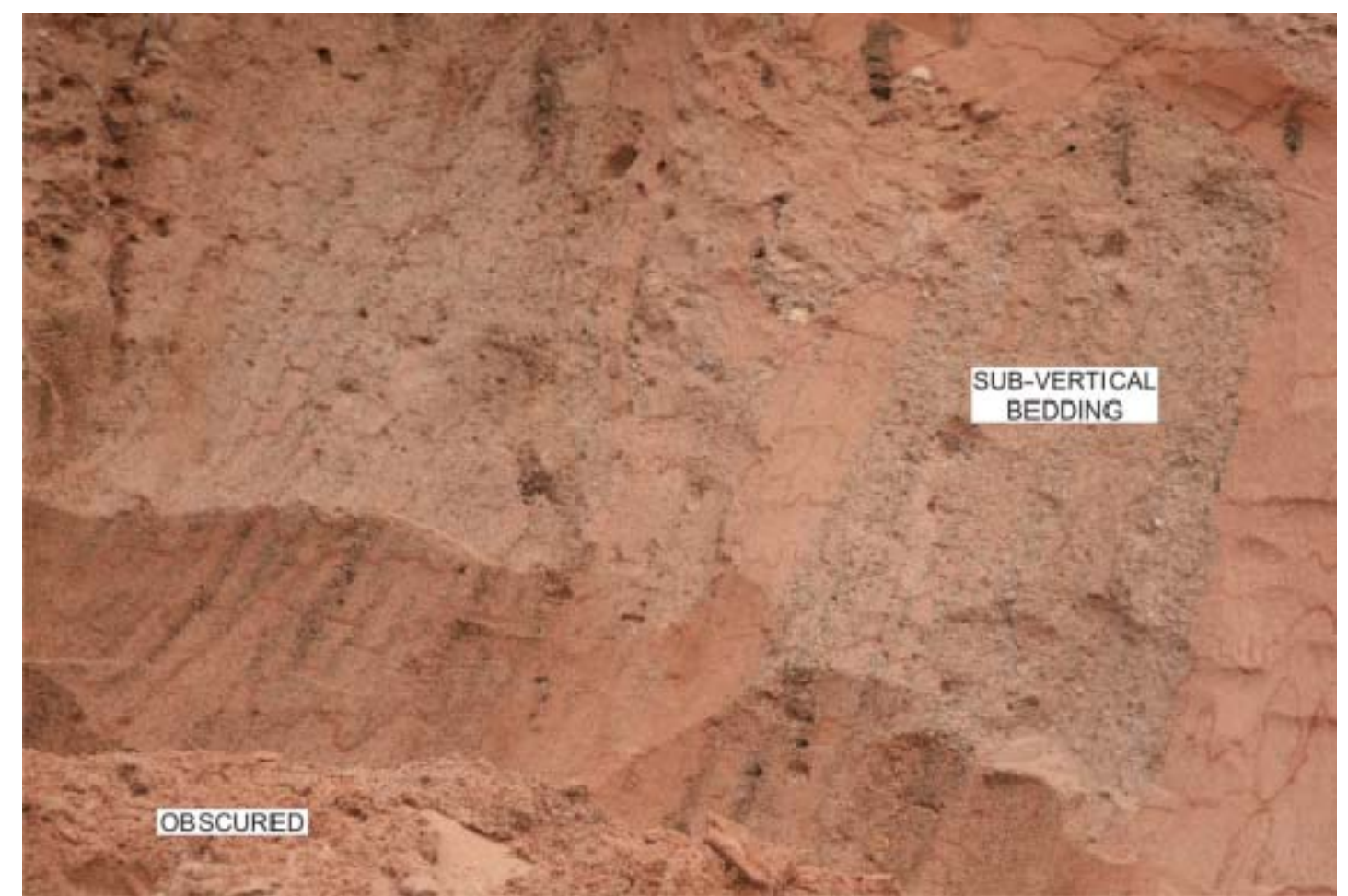

Figure 8 - Overturned gravel and sand deposits in Woore Hall Farm exposure. Trowel for scale. 


\section{References}

Andersson, G., 1997. Genesis of hummocky moraine in the Bolmen area, southwestern Sweden. Boreas, 27, 55-67.

Bakker, M.A.J., 2004. The internal structure of Pleistocene push moraines: A multidisciplinary approach with emphasis on ground penetrating radar. Published PhD thesis by TNO-Geological Survey of the Netherlands.

Benediktsson, Í.Ö., Möller, P., Ingólfsson, Ó., van der Meer, J.J.M., Kjær, K.H. and Krüger, J., 2008. Instantaneous end moraine and sediment wedge formation during the 1890 glacier surge of Brúarjökull, Iceland. Quaternary Science Reviews, 27, 209-234.

Benn, D.I., and Evans, D.J.A., 1997. Glaciers and Glaciation. Arnold, Hodder Headline Group, London.

Bennett, M.R., 2001. The morphology, structural evolution and significance of push moraines. Earth Science Reviews, 53, 197-236.

Bennett, M.R., Hambrey, M.J., Huddart, D. and Glasser, N.F., 1998. Glacial Thrusting \& Moraine-Mound Formation in Svalbard and Britain: the example of Coire a'Cheud-chnoic (Valley of a Hundred Hills), Torridon Scotland. Quaternary Proceedings, 6, 17-34.

Bennett, M.R., Huddart, D., Waller, R.I., Cassidy, N., Tomio, A., Zukowskyj, P., Midgley, N.G., Cook, S.J., Gonzalez, S. and Glasser, N.F., 2004. Sedimentary and tectonic architecture of a large push moraine: a case study from Hagafellsjökull-Eystri, Iceland. Sedimentary Geology, $172,269-292$.

Blott, S.J. and Pye, K., 2001. GRADISTAT: A grain size distribution and statistics package for the analysis of unconsolidated sediments. Earth Surface Processes and Landforms, 26, 12371248.

Boulton, G.S., 1968. Flow tills and related deposits on some Vestspitsbergen glaciers. Journal of Glaciology, 7, 717-735.

Boulton, G.S., 1978. Boulder shapes and grain-size distributions of debris as indicators of transport paths through a glacier and till genesis. Sedimentology, 25, 773-799.

Boulton, G.S. and Clark, C.D., 1990. A highly mobile Laurentide ice sheet revealed by satellite images of glacial lineations. Nature, 346, 813-817.

Boulton, G.S. and Hagdorn, M., 2006. Glaciology of the British Isles Ice Sheet during the last glacial cycle: form, flow, streams and lobes, Quaternary Science Reviews, 25, 3359-3390

Boulton, G.S., van der Meer, J.J.M., Beets, D.J., Hart, J.K. and Ruegg, G.H.J., 1999. The sedimentary and structural evolution of a recent push moraine complex: Holmstrømbreen, Spitsbergen. Quaternary Science Reviews, 18, 339-371.

Boulton, G.S. and Worsley, P., 1965. Late Weichselian Glaciation in the Cheshire-Shropshire Basin. Nature, 207, 704-706. 
Bowen, D.Q., Phillips, F.M., McCabe, A.M., Knutz, P.C. and Sykes, G.A., 2002. New data for the Last Glacial Maximum in Great Britain and Ireland. Quaternary Science Reviews, 21, 89101.

Bradwell, T., Stoker, M.S., Golledge, N.R., Wilson, C.K., Merritt, J.W., Long, D., Everest, J.D., Hestvik, O.B., Stevenson, A.G., Hubbard, A.L., Finlayson, A.G. and Mathers, H.E., 2008. The northern sector of the last British Ice Sheet: Maximum extent and demise. Earth Science Reviews, 88, 207-226.

Chiverrell, R.C., Thomas, G.S.P. and Foster, G.C., 2008. Sediment-landform assemblages and digital elevation data: Testing an improved methodology for the assessment of sand and gravel aggregate resources in north-western Britain. Engineering Geology, 99, 40-50.

Ciner, A., Deynoux, M. and Çörekcioğlu, E., 1999. Hummocky moraines in the Namaras and Susam Valleys, Central Taurids, SW Turkey. Quaternary Science Reviews, 18, 659-669.

Clark, C.D., 1997. Reconstructing the evolutionary dynamics of former ice sheets using multitemporal evidence, remote sensing and GIS. Quaternary Science Reviews, 16, 1067-1092.

Clark, C.D. and Meehan, R.T., 2001. Subglacial bedform geomorphology of the Irish Ice Sheet reveals major configuration changes during growth and decay. Journal of Quaternary Science, 16, 483-496.

Clark, C.D., Hughes, A.L.C., Greenwood, S.L., Spagnolo, M. and Ng, F.S.L., 2009. Size and shape characteristics of drumlins, derived from a large sample, and associated scaling laws. Quaternary Science Reviews, 28, 677-692.

Cooper, A.H. and Gibson, A., 2003. Geology of the Leeds district - brief explanation of the geological map. Sheet explanation of the British Geological Survey. 1:50,000 Sheet 70 Leeds (England and Wales).

Croot, D.G., 1987. Glacio-tectonic structures, a mesoscale model of thin-skinned thrust sheets? Journal of Structural Geology, 9, 797-808.

Drozdowski, E., 1987. 'Surge Moraines', in: Gardiner, V. (Ed.) International Geomorphology. Wiley, Chichester, pp 675-692.

Evans, D.J.A. and Rea, B.R., 2005. Chapter 11: Surging Glacier Landsystem, in: Evans, D.J.A. (Ed.) Glacial Landsystems. Hodder Arnold, London, pp 259-288.

Evans, D.J.A., Phillips, E.R., Hiemstra, J.F. and Auton, C.A., 2006. Subglacial till: Formation, sedimentary characteristics and classification. Earth-Science Reviews, 78, 115-176.

Eyles, N., 1979. Facies of supraglacial sedimentation on Icelandic and alpine temperate glaciers. Canadian Journal of Earth Sciences, 16, 1341-1361.

Eyles, N., Eyles, C.H. and Miall, A.D., 1983. Lithofacies types and vertical profile models: An alternate approach to the description and environmental interpretation of glacial diamict and diamictite sequences. Sedimentology, 30, 393-410.

Goudie, A.S., 1990. The Landforms of England and Wales. Basil Blackwell. 
Ham, N.R. and Attig, J.W., 2001. Minor end moraines of the Wisconsin Valley Lobe, northcentral Wisconsin, USA. Boreas, 30, 31-41.

Hambrey, M.J. and Huddart, D., 1995. Englacial and proglacial glaciotectonic processes at the snout of a thermally complex glacier in Svalbard. Journal of Quaternary Science, 10, 313-326.

Harris, C., Williams, G., Brabham, P., Eaton, G. and McCarroll, D., 1997. Glaciotectonized Quaternary sediments at Dinas Dinlle, Gwynedd, North Wales, and their bearing on the style of deglaciation in the eastern Irish Sea. Quaternary Science Reviews, 16, 109-127

Hart, J.K., 1990. Proglacial glaciotectonic deformation and the origin of the Cromer Ridge push moraine complex, north Norfolk, England. Boreas, 19, 165-180.

Hart, J.K. and Boulton, G.S., 1991. The inter-relation of glaciotectonic and glaciodepositional processes within the glacial environment. Quaternary Science Reviews, 10, 335-350.

Hiemstra, J. F., Kulessa, B., King, E.C. and Ntarlagiannis, D., 2008. The sedimentological and geophysical anatomy of the 'Pigeon Point' drumlin in Clew Bay, Co. Mayo, Ireland. Quaternary Newsletter (February), 114, 46-51.

Hughes, A.L.C., Clark, C.D. and Jordan, C.J., 2007. Countrywide mapping of glacial landforms of the last British ice sheet. The Growth, Maximum Extent and Deglaciation of the last British and Irish Ice Sheets, Oral Presentation Abstract, QRA Annual Discussion Meeting January 2007.

Johnson, W.H. and Menzies, J., 1996. Pleistocene Supraglacial and Ice-Marginal Deposits and Landforms, in: Menzies, J. (Ed.), Past Glacial Environments; Sediments, Forms and Techniques. Glacial Environments 2. Butterworth Heinemann Ltd., Oxford, pp 137-160.

Jowett, A. and Charlesworth, J.K., 1929. The glacial geology of the Derbyshire Dome and the western slopes of the southern Pennines. Quarterly Journal of the Geological Society of London, 85, 307-334.

Kilner, M., West, L.J. and Murray, T., 2005. Characterisation of glacial sediments using geophysical methods for groundwater source protection. Journal of Applied Geophysics, 57, 293-305.

Kluiving, S.J., 1994. Glaciotectonics of the Itterbeck - Uelsen push moraines, Germany. Journal of Quaternary Science, 9, 235-244.

Knight, P.G., Jennings, C.E., Waller, R.I. and Robinson, Z.P., 2007. Changes in ice-margin processes and sediment routing during ice-sheet advance across a marginal moraine. Geografiska Annaler Series A - Physical Geography, 89, 203-215.

Kristensen, L., Juliussen, H., Christiansen, H.H. and Humlum, O., 2009. Structure and composition of a tidewater glacier push moraine, Svalbard, revealed by DC resistivity profiling. Boreas, 38, 176-186.

Krüger, J., 1994. Glacial processes, sediments, landforms and stratigraphy in the terminus region of Myrdalsjökull, Iceland. Folia Geographica Danica, 21, 1-233. 
Krüger, J., Kjær, K.H. and van der Meer, J.J.M., 2002. From push moraine to single-crested dump moraine during a sustained glacier advance. Norsk Geografisk Tidsskrift, 55, 87-95.

Krzyszkowski, D., 2002. Sedimentary succession in ice-marginal fans of the Late Saalian glaciations, southwestern Poland. Sedimentary Geology, 149, 93-109.

Krzyszkowski, D. and Zieliński, T., 2002. The Pleistocene end moraine fans: controls on their sedimentation and location. Sedimentary Geology, 149, 73-92.

Kulessa, B., Clarke, G., Hughes, D.A.B. and Barbour, S.L., 2007. Anatomy and facies association of a drumlin in County Down, Northern Ireland, from seismic and electrical resistivity surveys, in: Hambrey, M.J., Christoffersen, P., Glasser, N.F. and Hubbard, B. (Eds.) Glacial sedimentary properties and processes, Special Publication of the international Association of Sedimentologists, 39, pp 165-176.

Kupsch, W.O., 1962. Ice-thrust ridges in western Canada. Journal of Geology, 70, 582-594.

Lewis, H.C., 1894. Papers and notes on the glacial geology of Great Britain and Ireland. Longmans, Green \& Co., London.

Lindén, M., Möller, P. and Adrielsson, L., 2007. Ribbed moraine formed by subglacial folding, thrust stacking and lee-side cavity infill. Boreas, 37, 102-131.

Loke, M.H., 2004. Tutorial: 2-D and 3-D electrical imaging surveys. Online, available from: http://www.geoelectrical.com/download.html, accessed: $30^{\text {th }}$ January 2009

McCarroll, D. and Rijsdijk, K., 2003. Deformation styles as a key for interpreting glacial depositional environments, Journal of Quaternary Science, 18, 234-256.

McQuillin, R., 1964. Geophysical Investigation in a line of seismic shot holes. Bulletin of the Geological Survey of Great Britain, 21, 197-203.

Morgan, A.V., 1973. The Pleistocene geology of the area north and west of Wolverhampton, Staffordshire, England. Philosophical Transacations of the Royal Society of London. B265, 233-297.

Napieralski, J., Harbor, J. and Li, Y., 2007. Glacial geomorphology and geographic information systems. Earth-Science Reviews, 85, 1-22.

Oldale, R.N. and O'Hara, C.J., 1984. Glaciotectonic origin of the Massachusetts coastal end moraines and a fluctuating late Wisconsinan ice margin. Geological Society of America Bulletin, 95, 61-74.

Palacky, G.J., 1987. Resistivity characteristics of geological targets, in: Nabighian, M.N. (Ed.) Electromagnetic methods in applied geophysics, Vol. 1 - Theory, Society of Exploration Geophysicists, Tulsa, OK, Investigations in geophysics, 3, pp 53-129.

Paul, M.A., 1983. Chapter 3: The Supraglacial Landsystem, in: Eyles, N. (Ed.) Glacial Geology: An introduction for Engineers and Earth Scientists. Pergamon Press, pp 71-90. 
Pedersen, S.A.S., Petersen, K.S. and Rasmussen, L.A., 1988. Observations on glaciodynamic structures at the Main Stationary Line in western Jutland, Denmark, in: Croot, D.G. (Ed.) Glaciotectonics: Forms and Processes. Balkema, Rotterdam, pp 177-183.

Phillips, E.R., Evans, D.J.A. and Auton, C.A., 2002. Polyphase deformation at an oscillating ice margin following the Loch Lomond Readvance, central Scotland, UK. Sedimentary Geology, $149,157-182$.

Poole, E.G. and Whiteman, A.J., 1961. The glacial drifts of the southern part of the Shropshire-Cheshire Basin. Quarterly Journal of the Geological Society of London, 115, 1-15.

Rees, J.G. and Wilson, A.A., 1998. Geology of the country around Stoke-on-Trent. British Geological Survey Memoir for 1:50,000 Geological Sheet 123 (England and Wales). The Stationary Office, London.

Reynolds, J.M., 1997. An Introduction to Applied and Environmental Geophysics. John Wiley \& Sons, Chichester, England.

Sadura, S., Martini, I.P., Endres, A.L. and Wolf, K., 2006. Morphology and GPR stratigraphy of a frontal part of an end moraine of the Laurentide Ice Sheet: Paris Moraine near Guelph, Ont, Canada. Geomorphology, 75, 212-225

Sarala, P., Johansson, P. and Valkama, J., in press. End moraine stratigraphy and formation in the southwestern Pyhä-Luosto fell area, northern Finland. Quaternary International.

Doi: 10.1017/j.quaint.2008.11.005

Shotton, F.W., 1966. The problems and contributions of methods of absolute dating within the Pleistocene period. Quarterly Journal of the Geological Society of London, 122, 356-383.

Shotton, F.W., 1967. Age of the Irish Sea Glaciation of the Midlands. Nature, 215, 136-137.

Smith, M. J. and Clark, C.D., 2005. Methods for visualization of digital elevation models for landform mapping. Earth Surface Processes and Landforms, 30, 885-900.

Smith, M.J., Rose, J. and Booth, S., 2006. Geomorphological mapping of glacial and forms from remotely sensed data: An evaluation of the principal data sources and an assessment of their quality. Geomorphology, 76, 148-165.

Smith, R.C. and Sjogren, D.B., 2006. An evaluation of electrical resistivity imaging (ERI) in Quaternary Sediments, southern Alberta, Canada. Geosphere, 2, 287-298

Tchoukanski, I., 2008. ET Spatial Techniques Easy Calculator v5.0. Online, available from: http://www.ian-ko.com, accessed: $13^{\text {th }}$ June 2008.

Thomas, G.S.P., 1984. The origin and glacio-dynamic structure of the Bride moraine, Isle of Man. Boreas, 13, 355-364.

Thomas, G.S.P. and Chiverrell, R.C., 2007. Structural and depositional evidence for repeated ice-marginal oscillations along the eastern margin of the Late Devensian Irish Sea Ice Stream. Quaternary Science Reviews, 26, 2375-2405. 
van der Wateren, D.F.M., 1981. Glacial tectonics at the Kwintelooijen sandpit, Rhenen, the Netherlands, in: Ruegg, G.H.J. and Zandstra, J.G. (Eds.), Geology and Archaeology of Pleistocene Deposits in the Ice-Pushed Ridge near Rhenen and Veenendal. Mededelingen Rijks Geologische Dienst, 35 (2/7), pp 252-268.

van der Wateren, D.F.M., 1985. A model of glacial tectonics, applied to the ice-pushed ridges in the central Netherlands. Bulletin of the Geological Society Denmark, 34, 55-74.

Waller, R.I. and Tuckwell, G.W., 2005. Glacier-permafrost interactions and glaciotectonic landform generation at the margin of the Leverett Glacier, West Greenland, in: Harris, C. and Murton, J.B. (Eds.) Cryospheric Systems: Glaciers and Permafrost. Geological Society, London, Special Publications 242, pp 39-50.

Williams, G.D., Brabham, P.J., Eaton, G.P. and Harris, C., 2001. Late Devensian glaciotectonic deformation at St Bees, Cumbria: a critical wedge model. Journal of the Geological Society of London, 158, 125-135.

Worsley, P., 1970. Chapter 4: The Cheshire-Shropshire Lowlands, in: Lewis, C.A. (Ed.) The Glaciations of Wales and Adjoining Areas, Longman Publishers, London, pp 83-106.

Yates, E.M. and Moseley, F., 1958. Glacial lakes and spillways in the vicinity of Madeley, North Staffordshire. Quarterly Journal of the Geological Society of London, 113, 409-428.

Yates, E.M. and Moseley, F., 1967. A Contribution to the Glacial Geomorphology of the Cheshire Plain. Transactions of the Institute of British Geographers, 42, 107-121. 